\title{
ANDRÁS SAJÓ• \\ Promise and Contract: On the Limited Role of Social Ideas
}

\begin{abstract}
The essay is devoted to the role of promise as a moral concept, and, more narrowly, the relationship of promise and offer in contract law. First, it considers the difference between "ordinary" promises and promises having a legal effect. Secondly, the analysis explores to what extent does promise generate obligation. Thereafter, the essay attempts to point to the concept of obligation that provides the best way to establish the moral force of contract. It reaches the conclusion that the relationship between promise as a moral category and facts treated as promise in law is almost accidental. Law is at least indifferent to factors that give rise to moral obligation based upon a promise. However, law (emancipated from the dictates of morals) served freedom better than legal norms formulated in morally coloured terms.
\end{abstract}

Keywords: Promise, contract, obligation, self-obligation, freedom and autonomy, offer in contract law.

“Tonio Kröger ... stood before the cold altar, full of regret and dismay, at the fact that faithfulness was impossible upon this earth. Then he shrugged his shoulders and went his way."*

Gyula Eörsi, in his principal work titled Comparative Civil (Private) Law: Law Types, Law Groups, the Roads of Legal Development [Összehasonlitó polgári jog] by taking the role of law in society as a starting point, justifies a theory of legal development governed by practical needs. According to Eörsi, the "ultimately determining economic factors produce interests which unvariably have an influence on law through the transmission of ideas. Social ideas, as products of the mind, have a relative independence, but ideas which have an important bearing on society always have their roots

* András Sajó, Member of the Hungarian Academy of Sciences, Budapest, H1014 Budapest, Országház u. 30., Hungary.

E-mail: sajoa@jog.mta.hu

** Thomas Mann, “Tonio Kröger”, in: Thomas Mann: Death in Venice and Seven Other Stories, H. T. Lowe-Porter (trans.); New York: Vintage Books, 1930, 91. 


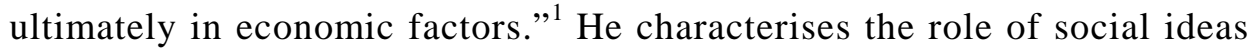
as "important but not basic".

The following analysis is devoted to the role of promise as a moral concept and, more narrowly, the relationship of promise and offer in contract law. Does law enforce the morals of promise, or, instead, does it enforce contractual obligations on the basis of more practical considerations determined by economic factors? Shifts in the public perception of the binding force of promises seem to have an impact on the law of contracts. However, Gyula Eörsi is right even after a quarter of a century: although the social idea of promise might have a significant impact on the law of contracts, it still is of secondary importance compared to economic interests that shape (or abandon) the social idea itself.

The questions to follow are dictated by moderate outrage. It is disturbing that the given word is not respected, or, more precisely, that even this very proposition concerning the normative basis of expectation is disrespected. It is embarrassing when moral norms are violated, but it is bothersome when the moral norm is taken as non-existent. Those who keep their promises and especially those who hope that others will do the same are taken as queer fish in our days. True, the principle of "ein Mann, ein Wort" was professed by merchants and by otherwise rather unattractive military officers. Characters of long passed times: it is a recurring motive of Eörsi's book that the time of the Buddenbrooks is over.

No era is marked for decline. In the words of Shakespeare: "Then fate o'er-rules, that, one man holding troth, A million fail, confounding oath on oath." "Yet, the decline of respect for promises is an important indicator of the state of a society. "To breed an animal which is able to make promises-is that not precisely the paradoxical task which nature has set herself with regard to humankind? Is it not the real problem of humankind?"3 - asked the great German philosopher. No, not Kant but ... Nietzsche. Nietzschein surprising conformity with Kant-celebrates the success of man in the ability to promise, in the "will's memory", in "an active desire not let go, a desire to keep desiring what has been, on some occasion, desired". ${ }^{4}$ The

${ }^{1}$ Eörsi, Gy.: Comparative Civil (Private) Law: Law Types, Law Groups, the Roads of Legal Development. Budapest, 1979, 45-46. The Hungarian original of the work was published as Összehasonlító polgári jog: Jogtípusok, jogcsoportok és a jogfejlődés útja. Budapest, 1975.

${ }^{2}$ Shakespeare, W.: A Midsummer-nights Tale; Act Three, Scene II.

${ }^{3}$ Nietzsche, F.: On the Genealogy of Morality (ed.: Keith Ansell-Preason). Cambridge, 1994, 38 (emphasis original).

${ }^{4}$ Nietzsche: op. cit. 39. 
man of promise, learning to render himself predictable, is able to have the future at his disposal. The man of promise can live up to his own image of the future. By making himself predictable, he became "a sovereign individual, ... like only to himself, having freed itself from the morality of custom, an autonomous and supra-ethical individual.",

As we live in an unhappy (but even in this respect unexceptional) age that needs heroes, ${ }^{6}$ the heroism of obligation-generating promises could do no harm. This is so, even knowing the sins of faithful perseverance. Those sins hardly affect the mystery of the promise, so long as a promise is seen as a means of human autonomy, and not of subordination.

The decline of the morals of promise is due to social and economic reasons, which can hardly be influenced. Still, may law, as a relatively independent normative system, come to the rescue of promise? After all, rumour has it that law is a manifestation and a pillar of morals. Considering the connection between contracts and promises that constitute contracts, and taking into account the central role of contracts in the functioning of law, it seems worthwhile to analyse how a promise may give rise to legal obligations.

In legal philosophy, turning Is into Ought is just like the philosophers' stone. How does an obligation emerge? Why are we obliged to do something? A realist would hold that and obligation is not more than a selfdeceiving expression of our desire to avoid punishment. An alchemist of legal philosophy may attempt to locate the source of obligations in some specific feature of promise. Promises can really give rise to moral obligations. Kant made gold but could not pour it into bars or turn in into fancy legal bijouterie. Law can not really make use of a moral obligation stemming from promise. Although Kant discussed promises giving rise to contracts in his theory of right, and not in his theory of morals, the discrepancy is even bigger than he would have ever had imagined.

Consider first the difference between "ordinary" promises and promises having a legal effect. A promise appearing in the context of the law of obligations, and especially in contract law, is a "promise aimed at a legal effect", "offer and acceptance", or declaration. Although this distinction is utterly justified under modern circumstances, a historical survey would suggest that there was another possible connection. Theoretically, it was

5 Nietzsche: op. cit. 40.

${ }^{6}$ One of Eörsi's favourite Brecht quotations. Brecht, B.: Life of Galileo, Scene 12, in: Brecht, B.: Collected Plays, vol. 5, (eds.: Ralph Manheim and John Willett); London, 1972, 85. 
and, even today, it is possible to establish a system of contract law, which consistently asserts that a promise in itself constitutes an obligation, and, even more, an enforceable one. Conceptual analysis is followed by a detailed discussion of this issue. This discussion, however, will not explore in detail why modern systems of contract law distanced themselves from the legal protection of moral obligations arising from promises.

Thereafter, the analysis explores to what extent does promise generate obligation. While there are several theories on this, the present discussion is centred around the Kantian concept, because the Kantian concept is based on freedom. Kant's metaphysic of morals provides moral norms of action as found in the state of freedom. Furthermore, the Kantian concept is the most consistent theory that locates the source of obligation in the person assuming an obligation. In comparison other theories appear to be heteronomous, as they justify obligations from the perspective of society or of the promisee, or they explain an obligation rising from a promise with reference to customs or coercion. Also, contemporary theories of contract, drawing on Aristotle, proceed from the aim of the promise, and not from the free expression of will exposed in a promise. These theories accept a promise as binding and a contract as valid, if the aim pursued by them is acceptable. Needless to say, such efforts seek the reformulation of law in terms of material justice, being in overt tension with other concepts of law based upon the autonomy of the promisor or the parties.

According to rivalling concepts, moral obligations stemming from promises differ in character and consequences-even for the purposes of law. The fourth section of the analysis is devoted to exploring which concept of obligation seems to provide the best way to establish the moral force of contract, and, in regulating contractual relations, what kind of moral order is reinforced and accepted by law. Experience suggests that the modern contact law is not guided by Kantian conceptions. Indeed, the same stands for modern legal systems in general, although allegedly the point of modern law is to safeguard liberty and a sphere of action for autonomous human beings. Legal norms - the promises of law-are indeterminate and disobeyed, features which suggest that the sovereign itself is not serious about its promises. Nonetheless, as suggested in the fifth part, this shall not prevent attempts to accord modern contract law with an individual moral of obligations pursuing Kantian conceptions of autonomy. May such efforts fail, an instrument for the critique of law has still been made available. 


\section{Promise and Contract}

Kant deals with promises in the context of acquisition by contract in his theory of right, when discussing the private law valid in the state of nature. Promise is an offer that can be pleasant for the one who accepts it.

Promise as a sign or phenomenon is quite different from legal phenomena. Using a term common in Hungarian legal terminology, a promise is not always of legal relevance [a "legal fact"], and even when it is a legal fact, it is often problematic to explain why it does not have a legal effect. In the ordinary sense of the word, any resolution addressed (communicated, intended to be directive or relative) to someone else concerning my actions amounts to a promise. In law only such public statements of will addressed to someone else are considered to be relevant, the addressee of which is identifiable. Certainly, such statements can be addressed to the general public. In his theory of right Kant discusses legally relevant promises in essentially similar terms.

According to Kant, it is only "the juridical relation of Man to Beings who have both Rights and Duties"7 that results in an actual connection between legal rights and duties. In Kant's analysis, however, although the binding force of law lies in itself, law must still correspond to morals. The notion of right implies the ability to bind others. Nonetheless, if law obliges one to do things that he should do anyway in compliance with his moral duties, then the legal order is a legal order of freedom. Thus, law derives from freedom, from moral law determined by our-selves. If my promise is not morally binding on me, no one can impose on me a legal obligation. Others who oblige me take advantage of the situation, which was created by the obligation implied in my promise. Taking advantage of an opportunity opened up by moral law, however, does not give rise to an obligation. Nevertheless, as soon as a moral obligation has been created, legal regulation takes advantage of it in a rather arbitrary fashion and allows others to make use of it as well, thereby distancing law from morals. For instance, contract law (i.e. legal regulations applicable to the enforcement of contractual obligations) treats the obligee's claims mainly without respect to the contents of the actual promise, and, thus, refusing to follow the morals of promise. Such ignorance is possible even for Kant: "it is not in Ethics, therefore, but in Jurisprudence, that the principle of

${ }^{7}$ Kant, I.: The Philosophy of Law, An Exposition of the Fundamental Principles of Jurisprudence as the Science of Right [Metaphysik der Sitten: Metaphysische Anfangsgrunde der Rechtslehre]. Clifton, 1974, 26. 
the legislation lies, that 'promises made and accepted must be kept'. Accordingly, Ethics specially teaches that if the Motive-principle of external compulsion which Juridical Legislation connects with a Duty is even let go, the idea of duty is sufficient itself as a Motive." 8

Kant was not at all the first to distinguish the moral binding force of promise from the binding force of contractual offer and acceptance, or contract itself. Kant-among others-dealt with the theory of right and virtue because it was obvious that actions, which follow the law of reason that was rendered possible in the state of freedom, do not necessarily occur in real life. Something must bring human actions closer to the state of freedom: this is what law is for. According to Kant, in contrast with moral law, legal rules provide for action not solely on the basis of moral obligations. If an action complies with the rule because it was guided by the idea of duty, then the action has morality ("duty of virtue"). At this point, Kant refers to promise as an example. ${ }^{9}$ A promise, which must be kept because of its enforceability, is a matter of legal obligation. But keeping a promise without external compulsion is an act of virtue ("fidelity").

According to Hungarian, French and German legal terminology and jurisprudence, a declaration which is not aimed to have a legal effect, does not give rise to a contract. The teleological character of the term "aim" might certainly become problematic. What should will and consciousness cover in order to trigger legal effects? An invitation to dinner might have connotations of boredom, dishwashing or a juicy stake for host and guest alike, while law does not cross their minds. Still, may one make a cruel joke out of a dinner invitation, when enforcing various legal consequences, the court will hold him for failing to seriously consider the foreseeable legal consequences of his actions.

Pursuant to classic common law, a gratuitous promise (where there is no consideration) does not give rise to a contract. Due to lack of acceptance (consideration) the promise is not legally binding. A sheer promise to transfer rights can not bring about a contract, since without consent there is no free act of will on the other side. In this case a promise does not establish and obligation, rather, it is a prolegomenon to self-binding. That is, anything that takes another person to consent qualifies as an attempt of self-binding. Binding force is attached to acceptance (consent, consideration), reliance, or confirmation by another person. Hegel's position highlights this point: "the two wills are associated in an identity in the sense that one of

8 Kant: op. cit. 22.

9 Kant: op. cit. 22. 
them comes to its decision only in the presence of the other". "My will may become objective to me."11 From the perspective of the morals of promise, however, acceptance is not constitutive, it reinforces the irreversibility of a promise at best. Kant himself says that a believed promise can not be withdrawn, since-using a modern term-it induces legal effects. Withdrawal is self-contradictory. More precisely, a person is bound by his promise until its withdrawn. Acceptance functions as a limitation on withdrawal, it bans withdrawal for the benefit of the acceptor.

Promisory estoppel and prompted interest (biztatási érdek), its Hungarian equivalent, show that a promise (actions inducing it or the impression thereof) may give rise to an obligation without acceptance (consideration). This happens when a promise induces action or forbearance of another reasonable person, who suffers damages as a result. Thus, it seems that promise as a moral obligation has limited relevance for law: it is necessary to exclude the arbitrariness of the enforcement of a consequence, which corresponds to the promise made. Consent implied in a promise, its voluntariness repeals the arbitrariness of legal coercion.

Modern legal systems distinguish promise from contractual offer and acceptance. Contract law applies to such promises which are about creating or transferring rights. From another perspective, legal consequences are manifested before performance if and only if the other party relied upon the declaration in question and was adversely affected. As Fuller and Perdue submitted in 1936, ${ }^{12}$ expectations generated by the offer or interest associated with actions based upon those expectations are protected by contract law.

In contemporary law, no one would be surprised if a statement concerning an expensive gift would only be enforceable if made in writing. (Hungarian professional discourse is likely to centre on who gets to counter-sign it and for how much exactly.) Why does law not recognise an obligation stemming from a sheer promise? Why does a simple declaration not suffice? Why is there a need for acceptance in case of a gift? The reason is not that law is hostile to promises, rather, it is because law serves legal policy considerations as well. And, mainly, without a requirement of writing, highly uncertain situations could emerge, raising innumerable problems of

\footnotetext{
${ }^{10}$ Hegel's Philosophy of Right [Naturrecht und Staatswissenschaft im Grundrisse/Grundlinien der Philosophie des Rechts]. London-Oxford-New York, 1967, 58 [s.74].

${ }^{11}$ Hegel's Philosophy of Right. op.cit. 58 [s. 73].

${ }^{12}$ See Fuller. L. L. and Perdue, W. R.: The Reliance Interest in Contract Damages, Yale Law Journal, 1936, 52.
} 
evidence. Practice and theory are content with insisting that insignificant promises are irrelevant; legal policy considerations are not questioned; for they are obvious. Zweigert and Kötz take the casebook example for granted: if someone is invited for dinner but not allowed to enter the house, he can not successfully claim compensation for his taxi bill. In the name of seriousness, issues of promise, offer and legitimate expectations are put aside without any theoretical analysis. English law goes as far as stating that "An Englishman is liable, not because he has made a promise, but because he has made a bargain." 13

\section{Protection of Promise in the History of Contract Law}

Roman law denied the binding force of a mere promise, and as such, the binding force of a promise of a gift. Canon law recognised the legally binding nature of promise, but its validity and enforceability depended on the aim served by the promise. Probably there was one moment in historyat the heyday of scholasticism-when contracts were meant to enforce promise-based obligations. In Gordley's view, however, this connection was based upon a conception of justice referring back to Aristotle. ${ }^{14}$

According to jurisprudence influenced by late scholasticism (Connanus, 1508-1551), the promisor was bound only in respect to belief. ${ }^{15}$ In a legal sense, a promise created an obligation to the extent breaching the promise would have violated the principle of "do no harm to others". Damages were adjusted to the credibility of a promise. Connanus' position was unacceptable for Grotius. First, Grotius, an advocate of natural law based on the law of reason, rejected Connanus' methodological presuppositions. Secondly, Connanus' position would also have destroyed Grotius' theory of international law. If a sheer promise is not legally binding, agreements of monarchs are irrelevant until they are being performed. And what is performance in the case of a peace treaty? Stopping the attacks, disbanding

${ }^{13}$ Cheshire-Fifoot (-Furmston): The Law of Contract; 1991, 28. On quote in: Zweigert, K.-Kötz, H.: Einführung in die Rechtsvergleichung. Tübingen, 1996, 385.

${ }^{14}$ This commutative justice consideration has been raising problems in law ever since. In this respect, in Hungary it is sufficient to refer to the confusion surrounding laesio enormis, abuses and unpredictability of public and private law.

${ }^{15}$ On this point, Atiyah and Gordley exceptionally seem to agree. See Atiyah, P. S.: An Introduction to the Law of Contract. Oxford, 1989, 10. Gordley, J.: The Philosophical Origins of Modern Contract Doctrine. Oxford, 1991, 73. See also Atiyah, P. S.: Promises, Morals, and Law. Oxford, 1981. 
troops, or what else? ${ }^{16}$ For a promise to be binding, or, for a promisor to be obliged to keep his promise, an a priori rule is needed. Grotius found this a priori rule in natural law: promises are binding by nature.

Grotius' position ${ }^{17}$ dominated social contract theories for a long time. Note that, although Grotius insisted that promises are binding, he was of the view that a promise is enforceable by the other party only if the promise was for transferring rights and if it was made in the proper form. In a similar fashion, Pufendorf believed that only those promises are "perfect" and, thus, enforceable which were made to transfer rights. It is not entirely clear whether by way of a perfect promise the promisor creates a claim, or whether it actually confers the right about which the promise was made. ${ }^{18}$ Natural law dictates that promises shall be kept. Still, the obligation itself is based on the voluntary consent to transfer something that belongs to one. A simple expression of future intent does not make a promise enforceable.

The idea to connect the binding force of promise with the binding force of contract gained further support in the Continent: in the sway of 18th-century freedom movements the concept of liberty was tied to autonomy. For the purposes of an attempt to make law correspond with liberty, the claim that "I am obligated because I obliged myself in my promise" sounds more attractive than any other competing explanation (e.g. I am obliged because the other party expects me to do something or did something). ${ }^{19}$ This is so since in all other cases the source of obligation is external. All this might be of little significance today, but in the 19th century the craftsmen of the basic-and still used-principles of contract law were eager to accord their conceptual devices with contemporary concepts of freedom.

This emancipation based upon the principles of freedom was not at all accomplished by legislatures of bourgeois revolutions-revolutionaries

${ }^{16}$ See Grotius, H.: De Jure Belli ac Pacis, II, XI.

${ }^{17}$ Grotius: op. cit., II. 11, IV.

${ }^{18}$ See von Pufendorf, S. F.: On the Duty of Man and Citizen According to Natural Law [De Officio Hominis et Civis Juxta Legem Naturalem], Cambridge, 1991, 70 [IX. 7.]

${ }^{19}$ There is a moment in Hungarian law, which is clearly dominated by promise. An offer sent by mail becomes irreversible from its receipt until the arrival of the response. Suppose that initially the addressee was hesitant to accept the offer and believes that no contract was made. Then, at the very last moment, he accepts the offer on the phone. 
were not concerned about moral elements of still preserved in law. Rather, they were bothered by the substantive and structural arbitrariness of law.

Members of the drafting committee of the Code Civil, while constantly referring to natural law and liberty, did not do more than editing Domat's ideas-ideas which were formulated before the revolution. In his remarks on contracts Domat did refer to freedom and will, in reality, however, all he (and others) did was cleaning law from concepts of scholastic theology, i.e. considerations of justice in quid pro quo. The creative jurists of the 18 th and 19th century were busy with trying to identify those promises among all morally binding undertakings, which could have a serious legal effect. In doing so they relied on technical factors independent of ethics and morals: they used tools as "causa" and "consideration". In lack thereof, a promise could not amount to an expression or will or offer. At the same time, "promise" was replaced by "will" in the terminology of continental private law. It is worthy of attention that early advocates of the will theory occasionally did refer to will as a manifestation of private autonomy. Law, even when it becomes positive, can serve the morality of freedom-to this extent Savigny summarised the Kantian concept properly. Law safeguards the sphere of individual freedom of action. Law promotes morality not by executing moral norms. Rather, via legal institutions law makes it possible for everyone to realise their inherent moral qualities in conformity with the nature of things. ${ }^{20}$ In sharp contrast with justice based approaches, Savigny insists that besides freedom "there is no need for a second principle in the name of the common good". ${ }^{21}$

According to Gordley, however, Savigny's concept of freedom and his will theory are not connected to Kant. ${ }^{22}$ It is not longer promise that is binding-promise was replaced by will itself. A contract originating from the conformity of wills is but a metaphor. Nothing follows from two (expressions of) wills. Wills and words standing for them are not two atoms bonded in a molecule, the existence of which generates a new physical reality. Initially, craftsmen of the modern (Pandectist) contract theory did acknowledge this. In the words of Savigny, the act of willing is "an invisible event". An act of willing can only be inferred from an expression of the will. Still, an expression may only be relied on to speculate about the possible will expressed.

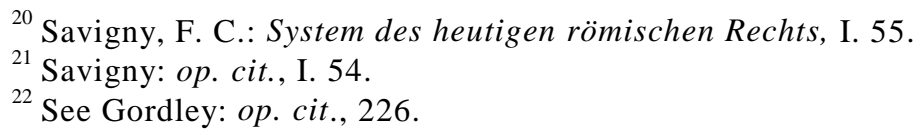


The legal treatment of the binding force of an offer demonstrates how limited respect for freedom is, when it is contingent upon the respect of will. Law determines the unilateral binding force of the offer-including its commencement and duration-in an automatic fashion, without regard to the intent of the offeror. Considerations about trade security serve as a standard justification for the rule, which is appropriate. Nonetheless, it clearly shows how law distanced itself already in the 19th century from the idea of will and from the promisor.

Replacing the problem of promise with the problem of the expressed will successfully detached contracts from the issue of moral binding force associated with promise, emancipated it from the confusing remains of moral thinking. The man of practice does not have to consider why a contract is binding. Promise emerged a novo as the moral basis for contract in the name of the protection of private autonomy when will theory lost its strength, owing not only to social and justice considerations, but also due to its own operational difficulties (e.g. problems of long-term co-operation, etc.). A purely formal theory of corresponding wills was hardly able to provide a justice-based revision of contract law, to reject its modern limitations. A morality-based theory that can refer to autonomy may be more successful in this respect.

\section{Is a Promise Binding, And If So, Why?}

Stricto sensu, promise gives rise to moral obligation if it commands the promisor "from inside", without reference to external reasons, that is, if the promisor obliges himself by the promise. This position is clearly reminiscent of the Kantian concept of establishing obligations. The most convincing are those moral theories, which derive the moral obligation to keep a promise from individual autonomy. The promisor's freedom receives its fullest recognition in this approach: the promisor is bound only with regard to himself, he is the cause of his own action. Other conceptions of the binding force of promise take the position of the recipient, the acceptor or beneficiary as a starting point. These theories explain the binding force of promise as a matter of responsibility triggered by the acceptor's reliance on the promise. Furthermore, due to their influence on contract law, it is important to mention those moral conceptions which explain promise as a convention necessary for the functioning of society, without reference to corresponding duties. Also, there are theories which connect the binding force of promise with coercion mobilised in response to non performance. 
Hobbes and Locke established the state by way of a contract. According to Locke, the power of government is based upon keeping mutual promises. ${ }^{23}$ As Hume pointed out, however, Locke could not succeed in justifying why the contract itself was binding. The idea that promise in itself might have some particular quality that makes it binding did not occur to Locke. As he argued against Aristotle, concepts and things had no essence for him. By rejecting essentialism Locke held, that promise is binding for otherwise the concept would not make sense. May this be the case, it still is no answer to the question. Promise certainly embodies the notion of acting upon an obligation that was undertaken voluntarily, and the concept is used in this sense. Still, a given use of a concept does not lead to an obligation to act according to a certain meaning, or, at best, it directs behaviour in the conventional sense of the word: meaning would be impossible without a certain correspondence of actual actions. Those who use the word "promise" generate expectations in the addressees.

While this solution is popular even today, Hume was not content with it. According to him, the true explanation of binding force is a matter of convention. Within the context of direct relations of small societies, sanctions against those who failed to keep their promises generated a convention, which was then partly reinforced by law. In small societies, promise is aimed at co-operation (motivated primarily by self-interest). Breaking a promise renders this co-operation impossible. Expectations developed this way were internalised by time. This is why people act upon promises. ${ }^{24} 25$

According to Hume, one does not abandon up the benefits of his natural freedom without compensation. Promise, thus, is conditional: it becomes unconditional and binding only in exchange for consideration (in politics, it is the protection provided by government / the sovereign). Of course, other than the rationality of interests, nothing explains why keeping a promise should be tied to the performance of others. According to this approach, only those promises are binding which are kept due to

${ }^{23}$ Although the democracy of ancient Athens knew no constitution, was not based on promise-its political organisation existed without simultaneous events, any specific act of obligation, or any act of obligation concerning the future.

${ }^{24}$ See Hume, D.: A Treatise on Human Nature (eds.: Sir L. A. Selby-Bigge and P. H. Nidditch). 2nd ed. Oxford, 1992. 541 [Book III, Part II, s.8].

${ }^{25}$ This explanation, however, undermines the binding force of promise, since breaching a promise will only amount to the violation of a convention. See Fried, Ch.: Contract as Promise: A Theory of Contractual Obligation. Cambridge, Mass., London: Harvard University Press, 1981, 15. 
the dictates of self-interest (and of conceivable compulsion) - the rest does not count. This, however, makes promise an impracticable social institution, since the interests of the promisor are hard to foresee. This perception is in conflict with the concept of promise itself: under this approach a promise is not a statement about one's future actions.

Note, however, that Hume made an attempt to turn fidelity into a moral obligation via a self-limiting argument. He holds that people keep their promises, because society would crumble if promises were abandoned upon the dictates of self-love. Thus, rejecting the submission that promise is an act of self-biding brings by an even more absurd explanation. After all, the alternative explanation presupposes self-interested people caring for society, people who "limit themselves" by an ex post judgement driven by their concern for society, thus solving the bootstrapping problem. ${ }^{26}$ Still, when building a system on an empirical basis one has to acknowledge that people are free-riders. According to Hume, however, there is no need to base the obligation to obey the sovereign on some concept of promise (i.e. citizenship in modern terminology)—everything is "justified" by admitting that there is no society without allegiance and fidelity. The standard counter-argument holds that acknowledging the above will compel anyone to participation in upholding the institution. In a situation when selfinterest commands to the contrary, one is not likely to observe the binding force of a promise simply because otherwise the necessary institution will not function in the long run. That is, except if one is a moral being in the Kantian sense, or, if one is afraid of disclosure or coercion.

Furthermore, Hume submits that in local communities, breaching a promise has extremely serious consequences among the members of the community. Aristotle claims that the one who does not keep a promise in a community, can not be virtuous. This consideration, however, does not apply in relation to outsiders: deception of strangers does not matter, more precisely, it is an admirable feint. As to legal agreements, Roman public and private law alike attributed little significance to promises (the institution of naturalis obligatio gained significance only later, partly due to Greek influence). Enforceable promises were established by sacral acts. What mattered was transfer (traditio), performance itself-this was the bar to reclaiming a promised and transferred object, or recalling performance. While this solution is appropriate for the legal needs of closed societies, it became inconvenient for the purposes of trade in imperial Rome. The tribal

\footnotetext{
${ }^{26}$ Hume, D.: Of the Original Contract (1748), in: Hume, D.: Politcal Essays, (ed.: Knud Haakossen); Cambridge, 1994, 197.
} 
way of thinking, which attributes binding force to promises only within the group, is completely dysfunctional in modern, anonymous societies utterly settled upon exchange of goods. With the disappearance of the tribe as the natural background of binding promises, and in lack of a natural community within which promises should be kept, the fate of promise is sealed. There is no community any longer in which promises are to be kept: public sphere consists of strangers. ${ }^{27}$

According to sociological or (in the Kelsenian sense) pure concepts of legal theory, a promise giving rise to a right shall be kept due to external legal coercion. Quoting La Rochefoucauld: "we promise according to our hopes, and we hold according to our fears." 28

While for Locke contract is a means to construe government, for Hart promise is the baseline of the entire modern legal system. Hart regards legal rule itself as a promise. Legal rules are binding as promises. The legislator, the executive and the judiciary promise the application of the rule. For Hart, promise (and the legal rule that is in itself a promise) binds the promisor by way of external rules upon which the action promised is to take place. The binding force is dependent upon the external condition (the existence of

\footnotetext{
${ }^{27}$ On the other hand, transactions, both commercial and political, are not synchronic but lasting and multitudinous, thus, the need for mutual trust is increasing. In the anonymous mass society, social co-operation can function successfully only as an autonomous relation of free human beings, or in free relations of autonomous human beings. Empirically, it is hardly possible, perhaps because people lack the rationality necessary for making and keeping promises. A series of legal and social institutions is set up to substitute it-endangering autonomy itself, hindering the promises of the autonomous human being from being realised. Furthermore, contracts are not made by men anymore, they are made by organisations. The man of organisations is, of course, anonymous and enjoys the irresponsibility of anonymity. And as contracts that are dictated by organisations play a decisive role, the model of promise disappears, and even the people who creep forth from the mouth-hole of organisations behave as they are accustomed to. E.g. product liability (which is limited even today) exist for mainly political reasons and not owing to the logic of private law. Also, and more importantly, law tends to accept that one shall promise almost nothing to enter into a contract. Roughly speaking, a bank is keeping one's money as a deposit according to terms it wishes and conditions it sees fit. (Pursuant to the practice of the National Savings Bank ["OTP"] major cash disbursements may take place several days following prior notice-allegedly for security reasons. Nobody seems to care that this does not at all serve the interests of the depositor.) Does a statement that is subject to constant change fit within the concept of promise? And if the statement of bank is not a promise, then what is it? Mightiness based upon involuntary consent?

${ }^{28}$ de La Rochefoucauld, F.: Maxims. Baltimore, 1959. 38.
} 
the rule and some further factors behind the rule). Promise is to be kept for heteronomous, external reasons that do not concern the promisor. ${ }^{29}$ Hart takes promise as a means necessary in economic relations, as an instrument of self-biding. Empirically this approach might be close to contract law's notion of recognition of promise, but as a practical or utilitarian consideration, it amounts to an component of moral theory on law, and not a moral basis for law.

According to Kant, the action following one's own act of choice (reason) presents the action as objectively necessary, i.e. makes it a duty ${ }^{30}$ by adjusting it to the moral law. Just to avoid misunderstanding: "The activity of the Faculty of Desire may proceed in accordance with Conceptions; and in so far as the Principle thus determining it to action is found in the mind, and not in its object it constitutes a Power acting or not acting according to liking. In so far as the activity is accompanied with the Consciousness of the Power of the action to produce the Object, it forms an act of Choice". "It means (simplifying the point) that the act of choice is the action governed from inside and recognized as that. One keeps a promise because of the dictates of the law of reason. Any other action would be contradictory: if keeping promises is not rendered as the general standard of action, it will be impossible for anyone to promise. Promise ceases to exist just like the possibility of autonomous action.

"For, the universality of a law that everyone, when he believes himself to be in need, could promise whatever he pleases with the intention of not keeping it would make the promise and the end one might have in it itself impossible, since no one would believe what was promised him but would laugh at all such expressions as vain pretenses."32

${ }^{29}$ Hart, H. L. A.: The Concept of Law. 2nd ed., Oxford, 1998.

${ }^{30}$ See Kant: op. cit., 18.

${ }^{31}$ Kant: op. cit., 12.

${ }^{32}$ Kant, I.: Groundwork of the Metaphysics of Morals [Grundlegung zur Metaphysik der Sitten], (ed.: Mary Gregor); Cambridge, 1997, 32.

The first part of the above quotation reads as follows: "Another finds himself urged by need to borrow money. He well knows that he will not be able to repay it within a determinate time. He would like to make such a promise, but he still has enough conscience to ask himself: is it not forbidden and contrary to duty to help oneself out of need in such a way? Supposing the he still decided to do so, his maxim of action would go as follows: when I believe myself to be in need of money I shall borrow money and promise to repay it, even though I know this will never happen. Now this principle of self-love or personal advantage is perhaps quite consistent with my whole future welfare, but the question now is whether it is right. I therefore turn 
As the promisor follows his own law, his action corresponds to moral duty. But why does the rule of reason command promises to be kept? Duty is to be followed, says Kant. But why? When criticising Mendelssohn, Kant rejects the question itself. In his theory of right Kant submits: "The question is put thus: 'Why ought I to keep my Promise?' for it is assumed as understood as understood by all that I ought to do so. It is, however, absolutely impossible to give any further proof of the Categorical Imperative implied... It is a Postulate of the Pure Reason..."33 This remark applies to promise in contractual relations. So the question makes no sense in lawand only in law. George Fletcher, commenting upon Kant's above mentioned standpoint, finds that in contract law freedom of action falls under limitations by way of promise, as certain decisions are handed over to the other party. "The different outcomes under the moral and legal theory highlight divergent concerns: the former with the promisor's internal struggle and the latter with the problem of power and control between two distinct individuals." 34

Kant does not elaborate on the origin of the binding force of offer, finding that it is impossible to prove and shall be accepted as a categorical imperative. Nonetheless, outside the theory of right it well might be possible to find some moral reason that explains the binding force of promise. Then, this moral basis might affect law, and, by the same token, contract as well.

Certain versions of the Kantian conception do not take the promisor's relation to himself as the basis for the obligation to keep promises. In this respect, Charles Fried's attempt is remarkable. In his book of 1981 Fried establishes the binding force of modern contract upon promise: "since a contract is first of all a promise, a contract must be kept because a promise must be kept." ${ }^{, 35}$ According to Fried, men are free for they can

the demand of self-love into a universal law and put the question as follows: how would it be if my maxim became a universal law? I then see at once that it could never hold as a universal law of nature and be consistent with itself, but must necessarily contradict itself."

The Kantian tenet of self-contradiction and the collapse of the social institution of promise as its consequence can also be found in Locke and in Hume's conventionalism. Kant, however, connects those elements to autonomous action, and turns them into an internal law of action.

${ }^{33}$ Kant: The Philosophy of Law / Metaphysik der Sitten. op. cit., 103-104.

${ }^{34}$ Fletcher, D.: Law and Morality: A Kantian Perspective. Columbia Law Review, 1987. 533, 547.

${ }^{35}$ Fried: Contract as Promise. op. cit. 17. 
establish contacts with others, human freedom is realised in those relations, and this is the source of the binding force of promise-and, at the same time, its moral basis, as it is an act of freedom. "An individual is morally bound to keep promises because he has intentionally invoked a convention whose function it is to give grounds-moral grounds-for another to expect the promise performance. To renege is to abuse a confidence he was free to invite or not, and which he intentionally did invite." ${ }^{36}$ Immorality consists in abusing someone's confidence and, by way of that, not treating the other person as an autonomous being. This is morally wrong.

A variation of Fried's approach is to hold that the promisee's trust is an assumption regarding the promisor as an autonomous being. In this context failure to perform undermines the promisor's autonomy. One, who wants to be autonomous, also has to act as an autonomous being in relation to others. Promises must to be kept to avoid being seen as an abuser of confidence. Moral duty is replaced by virtue, or, perhaps, by the social sanction.

While Fried takes into consideration the promisor's morality, other theories seek the binding force of promise in its impacts on others who rely upon it. Promise triggers an expectation (confidence), and violating it is unjust or morally wrong. Scanlon, ${ }^{37}$ for example, derives the binding force of promise from the detrimental consequences caused by the violation of the promise to those who relied on it. According to principles requiring the avoidance of harm, a breach of promise adversely affecting another person is morally wrong. Everyone, including the promisor, is under a duty to refrain from causing disadvantage or harm to others. Avoiding wrongfulness is the promisor's moral duty. (Consequently, if a breach of promise is not detrimental, there is no violation of duty. The same applies when some greater harm is avoided by breaching a promise.)

When focusing on how the promisor may be discharged of the promise it is easy to point out the difference between this external justification of the binding force of promise implied in the assertion of claims and the Kantian justification that centres around the promisor. A promise is not to be kept if the promisee releases the promisor. Did the person released this way keep his promise? Shall he still condemn himself in foro interno? Furthermore, how shall an external observer view the ones favoured by

\footnotetext{
${ }^{36}$ Fried: Contract as Promise. op. cit. 16.

${ }^{37}$ See Scanlon, T. M.: Promises and Contracts. In: The Theory of Contract Law (ed.: Peter Benson). Cambridge, 2001.
} 
benevolence and equity? What kind of a freedom can be completely dependent upon others?

I regard a stricter version of moral obligation as valid. This approach seeks the basis of the obligation in the act itself, and not in the relationship with the addressee. If a promise is kept because someone else expects it (or enforces it), then the cause of the action does not lie in the actor. What makes a being autonomous is the reason why he keeps his promise. He does not keep his promise for he promised to someone else, but because of himself. The duty to oneself becomes the basis for keeping a promise. The obligation derives from one's own freedom and autonomy and not from the recognition of another's autonomy via a promise. Assuming an obligation is an act and a consequence of freedom. Following Kant, the person who acts upon an obligation, is a moral being-who chooses to follow the law of reason. Thus, acting in fulfilment of an obligation that originates from a promise amounts to a duty (unless the duty is not contrary to the law of reason, that is a very low standard). It means that by keeping a promise without regard to any other person, one justifies himself as a moral being.

Promise leads to self-obligation as follows.

Suppose that I have an idea concerning some future action of mine. I may go jogging in the park today. It is time to go jogging in the park, etc.

To this idea, I attribute the character of a decision. The question is what makes the idea of a future action into a resolution. The issue can be approached in an empirical way-I adjust some of my plans and particular actions to it. The connection can be rather weak when this adjustment remains on the level of ideas. But if I go to bed earlier or prepare my shoes, I actually reinforce my decision by actions. I may also underpin my resolution by means of social representation: I make a vow. For a religious person, this is a serious obligation as the believer exposes himself to the judgements and sanctions of an imaginary external force. The force can be external in the sense that in the case of breaching the vow, one anticipates the punishment of fate-that is, one attaches a sanction to it. But one does not have to be a believer to be able to self-oblige. Self-obligation might be a case of normal schizophrenia or the ability of man to reflect upon himself. What transforms an idea into a resolution is that one renders the realization of the resolution to become the measure of his moral judgement on himself. Certainly, this is possible on different levels of consciousness, and can work not only in anticipation but subsequently as well. I have not gone jogging for a week (with all sorts of excuses)-if I do not go tomorrow, I am a good-for-nothing (lazy, stupid, etc.) man. (The 
condemnation might be not only moral, but also intellectual, although even in the latter case it has a moral fault behind it. Stupidity or ignorance of health is one's moral fault.)

Suppose that I announce: from now on, I will go jogging every morning (I make an announcement that I made a vow to myself on jogging). ${ }^{38}$ This promise will already be subject to sanctions (backbiting, contempt, etc.). What will be the ground for contempt? My own breach of obligation. I will be condemned for breaching my obligation, although my action was not detrimental to anyone else, no one could establish any material expectation on me: the action concerned only myself.

Telling someone that "I promised myself to go jogging from now on" is not a promise in the legal sense of the word. It is different than saying: "I promise you to go jogging every morning". In a legal system based on the morals of promise, it would be a promise giving rise to an obligation, an enforceable promise. Whether law will really provide protection against breaching this promise is a different matter. After all, what kind of right did I confer upon the promisee? A right to see me jogging? Without conferring a right, there is no contract, no legal obligation.

Before dwelling on the possible legal relevance of the concept of "promise as obligation", it is in place to mention a potential practical counter-argument. With becoming widespread such a practical approach undermines the very possibility of moral existence in everyday life. "Undermining" describes a situation where insisting on promises results in a recurrent failure of one's way of living. The counter-argument holds that it is completely irrelevant how one defines himself-all that matters is the social context. The whole line or argument is foolish, it is the logic of the blockhead. Why would it be wrong to depart from one's resolution? Why should one do something that is unpleasant or that is against his interests? The principle of pacta sunt servanda is based on the premise that an offer can not be against the offeror's interests, as there is consideration for his performance. Where public opinion does not find the interest satisfied, promise is not binding and it does not have to be kept. Adaptation is freedom itself. Even the promise made to someone else is not to be kept unless the other party can force me to perform. As others have expectations, and costs based on those expectations, others put a system [like law] in motion if observing a promise is instrumental to their interests.

This line of argument allows for the existence of promise only as mere reflectivity. Empirically a promise is binding to the extent there is a chance

${ }^{38}$ Atiyah deals with this issue in another context. See Atiyah: Promises. op. cit. 54. 
for successful enforcement. This approach may culminate in destructive tendencies: the less likely it is to expect a promise to be kept, the more resources are needed for the enforcement thereof. In the meantime, the chances of calling an amoral promisor to account are diminishing, due to the availability of limited resources. Various dubious and desperate efforts were made in modern times to devise techniques for securing performance; solutions range from expensive guarantees to blacklisting violators and non-performers. Still, modern law and modern standards of conduct widely tolerate non-performance, they settle for paying damages. In these cases the amount of damages is adjusted not to the value of a promise, but to the "reasonability" of the expectation generated by the promise. In trade relations it is acceptable to breach a promise and to deliver to someone else, if the other person pays a higher price. A seller is reasonable as long as the profit made this way is higher than the damages to be paid, that is, as long as the contracting party suffering harm can obtain the goods at a price lower than the price received by the seller. According to economic analysis, this is about cost-effective expenditure, and, thus, constitutes a reasonable course of action. Morality seems to be irrational. Coercion to enforce a promise is expensive. Then why keep a promise? No one will be caught anyway.

Any conception that takes promise as generating some obligation must respond to the following problem. ${ }^{39}$ I receive a thousand pounds in exchange for promising that I will pay it back. Do I have to pay it back because I received it? Or because I promised to repay it? More people believe that they would pay the money back because they had received it, because it does not belong to them. It may well be that this conception is backed by respect for property, and not by ethical premises upon the principle of promise. It would be unjust to keep what belongs to someone else. As a result of a failure to follow the rule voluntarily, what is owed might be taken away in line with the requirements of corrective justice. Logic behind the rule of positive law also promotes the interest in seeing a loan returned: it has to be returned because it was given. The enforcement of returning a loan is not based on the binding force of promise; promise is almost irrelevant from a legal perspective, or from the perspective of the creditor. For law a promise to repay is less relevant than restoring the state of affairs that conforms with justice. That is, regardless of promise, a usurious interest rate on a loan does not have to be paid. Morally, for autonomous morals of obligation, one is not condemned for having obtained

${ }^{39}$ Atiyah: Promises. op. cit. 34. 
something, but because of the promise made in regard to that thing. Otherwise this case would be similar to finding a banknote, even knowing to whom it belongs-and not handing it over. This is not a great honour, but is not a problem of fidelity either.

Promise is an act of freedom by which one establishes a rule to himself. If someone does not admit to being bound by his promise, he excludes his own freedom. Freedom is justified by way of voluntary (in Kantian terms, arbitrary) constraint, by voluntary self-denial. One has free will (one is free) only in case what is willed derives from himself, if one sets tasks for himself.

\section{The Relationship of Promise and Obligation Asserted in Contract and in Contract Law}

Contract law preserves something from the moral characteristics of promise. According to Fried contracts can be understood in light of promise as a moral concept. Scanlon holds that the similarities between promise and contract are due to shared values they are rooted in. Although, as Scanlon adds, these values trigger different reactions in law and in moral theory, thus, promise and contract are parallel concepts. ${ }^{40}$

There are various, competing conceptions on the moral binding force of promise. Furthermore, despite all attempts of international unification, legal families provide different solutions. What is the role of obligation established by a promise in legal solutions?

Kant sharply contrasts duties of virtue and duties of right, i.e. duties that can not be based upon the sense of duty that is to be found in every rational being. ${ }^{41} \mathrm{~A}$ creditor can not tell a debtor that "you are obliged to pay it back by your own reason". Still, there is such a moral obligation. In principle, it would be possible for a legal rule to enforce promise-based obligations. At certain points in history, law was not far from this, and the established principles of modern continental legal systems seem to correspond. Law, even if it becomes positive, can serve the morality of freedom. Even Savigny, this rather authoritarian Prussian minister of justice, thought that he had to believe and proclaim it.

Regarding the relevance of promise for contract law, it is important to examine certain factors which create the impression that promise (the contents of an offer) is of secondary significance, if not irrelevant al-

\footnotetext{
${ }^{40}$ See Scanlon: Promises... op. cit. 86.

${ }^{41}$ See Kant: The Philosophy of Law / Metaphysik der Sitten. op. cit., 24-26.
} 
together. Especially German jurisprudence excels in reading clauses into contracts never contemplated by the parties. Nonetheless, promise, or offer may be relevant even if it does not cover the promised performance or its conditions. Also, if a party is released from a contract due to the change of circumstances [clausula rebus sic stantibus], it is not to mean that promises are not binding. The promisor's intent does not have to extend to complicated future situations. In principle-unless there is a reason to suppose otherwise-it is acceptable as a premise that a promise covers everyday, common or foreseeable situations, ${ }^{42}$ and it is binding to such extent. Note that a promise is an act of freedom and is universalisable to the extent it complies with rules of reason.

In order to examine the validity and predictive force of various moral conceptions, it is instrumental to compare their views on the moral binding force of promise and the legal regulations of performance at the three stages of the contract's existence. Such an analysis might reveal moral conceptions underlying contemporary legal regulations. The three stages to examine are: conclusion of the contract - with particular reference to the binding force of offer; performance-focusing on the requirement of good faith and co-operation; and breach of contract - concentrating on the target of legal sanctions.

1. How long is the offeror bound by the offer without any contractual stipulation in this regard? And, provided that promise has any significance, may the offeror set a date for that ex post? Regarding the binding force of an offer, common law and civil law jurisdictions developed radically different solutions. ${ }^{43}$ Under common law, an offer may be revoked any time before its acceptance, even in if the offer contained an express stipulation on its validity. This is an instance of complete disregard of the principle of promise. This effect is somewhat eased as the rule does not apply to offers made upon consideration. The binding force of an offer, thus, depends on an external factor, although not on the expectations of another person. In U.S. jurisprudence an offer is not revocable irrespective of consideration, when another person acted relying on the offer. The freedom of revoking an offer is further relaxed, as acceptance does not have to reach the offeror: an offer becomes irrevocable when acceptance is placed in the mailbox of the offeror.

In Romanist legal systems, and, thus, in French jurisprudence, damages are due if an offer is revoked before its acceptance. Courts determine the

${ }^{42}$ BH 1986/11. 469.

${ }^{43}$ See Zweigert-Kötz: op. cit., 351. 
binding force of offer on a case-by-case basis. Some hold that damages are due because the revocation of an offer breaches a fictitious preliminary contract on the binding force of the offer. This is the fiction of the promise principle. According to another conception, however, this is a tort-a conception which is in accord with Scanlon's views.

Pursuant to the promise-based solution of Art.862(3) of the Austrian Civil Code (ABGB), the offeror is bound by his offer, he could not be released by any act of revocation. S.145 of the German Civil Code (BGB) provides a similar solution. The offeror has to state that the offer was made ohne obligo, this way turning the offer into a call for offers (tender), which upon acceptance is then transformed into a consent by silence on the basis of the principle of co-operation in good faith (Treu und Glauben). In theory this is a case for the morals of promise. Courts, however, are tampering with such promises. In addition, an offer is effective until it reaches the addressee. Regarding this rule the findings of Zweigert and Kötz are characteristic of a legalistic approach. They hold that the German solution is rational because the events are controlled by the offeror, thus, it makes perfect sense to allocate risks on his side.

The approach of the Hungarian Civil Code is also radical: an offer, a promise, is transient unless the will wants it otherwise. But the offer (the "expression of intent") by its nature seems to disperse into air, unless the watchful acceptor catches it with the butterfly-net of his will before it would vanish altogether. This solution is utterly reasonable for the purposes of trade security. Still, what kind of promise is this, from the perspective of the binding force of promise? In the case of transactions between parties who are not present, the offer is binding as long as a response may be expected under ordinary circumstances. Pursuant to Art. 211(2) of the Hungarian Civil Code, the usual period is to be estimated with regard to the means of transmission. To this extent the Hungarian Civil Code is closer to the promise-principle, although it supplements the promise principle with trade customs and practices. The means of sending the offer may indicate the durability of a promise. To the extent the validity of a promise is established on the basis of its form, the reference to trade customs is used to establish the binding force of the promise. Still, the custom applicable to the arrival of the offer is about the qualities of performance, and not of promise itself. No matter how reasonable, the rule reinforces trade customs and practices, but not promise. Therefore, it does not follow the logic of self-binding reflected in promise. Promise, or will, creates an occasion for applying legal conventions.

Promise as a source of obligation is secondary even in German and Hungarian law. Will mainly stands to make it possible for a party to 
subject himself freely to the rules of the game prescribed in law. Even if it is supposed that the moral of promise is acknowledged in positive law, unless there are express reservations, an offer does not serve the observance of a promise-it binds the promisor pursuant to conventions defined in contract law. The logic of these conventions is by no means adjusted to the promisor's moral absolutism. Instead, it is guided by considerations on trade security and risk allocation. Conventions on the binding force of offer do not maximise the binding force of promise. Without an express disposition of the offeror, the choice of an autonomous subject is rather limited: he makes an offer by mail, by telephone, his offer is about sale and purchase, lease, etc. What is not mentioned in the offer, is added by statute and by courts. Such supplements, however, do not respect the presumable will of the offeror. With a rough offer, the offeror submits himself to contractual conventions. Like a chess-master, the offeror may pick an opening. A contracting party, however, has less freedom than a chess player, as parties to a contract shall make their further moves in compliance with the law. This is far stricter of a constraint than deciding which figure to move. A contracting party who is silent about cogent and dispositive rules is like a chess player with no creativity, a player who opts for Nimzo indian defense and, after the opening, sticks to the moves of game 21 of the Capablanca-Alekhine title match of 1927.

2. Co-operation upon good faith is the guiding principle of the Hungarian Civil Code. This would even follow from the concept of promise: if a promise is binding, one has to act upon it as long as the promise is effective. Good faith concerns primarily the promisor. Secondarily and consequently, it also concerns the other party who makes a promise in respect to his consideration. The promisor-according to the convention concerning promise or his own law of reason-has to suppose that his partner is acting in good faith. Indeed, promise corresponds to a "univerzalisable" law of reason in the sense and to the extent that every promise establishes an obligation. Hence, one has to regard as binding not only his own promises but also those promises made by the other party, at least until the other party breaches his promise, or until one can reasonably suppose that the other party will breach his promise (the latter being recognized by English law as anticipatory breach). Without a specific meaning attributed to it in law, an expression of will would mean that a promise is to be taken seriously, one can not be released from it upon random excuses. According to Cicero, it is unjust to breach a standard created for ourselves: "justice rests upon the foundation stone of good faith, that is to say, truthfulness 
and scrupulous observance of promises and covenants ... [T] he term fides, 'good faith', originally signified a promise which has been kept (fiat)". ${ }^{44}$ Law can do nothing about it. Economy needs average dishonest people who set up rules for themselves, or at least such judges are needed who would decide accordingly. In the name of fairness and good faith, one does not have to do everything at all to keep a promise. The standard of liability for cooperation is what is generally expectable in a given situation.

3. Breach of contract. In order to render the rules of the game unambiguous, the accomplishment of private law is to provide sanction for breach of conventions. Primarily this is achieved not by enforcing a proper step, i.e. a convention. A solution unusual in private law is to punish the mischief (although see the crimes of bankruptcy). Or, as a far more typical reaction, it proceeds from the assumption that the other party is expected to follow the law, and, thus, private law puts the party who (supposedly) relies on the behaviour of the other party to a state in which he would have been if the rule had been complied with. But private law does not restore or create a state called for by the promise. When contract law, or civil law in general, concentrates on damages caused by a certain conduct, it turns out to be indifferent about the conduct itself.

As to expectations concerning the performance of a contract, at the outset, there is a remarkable difference between common law and civil law legal systems that were under Pandectist (and later German) influence. By now these systems, despite textual and doctrinal differences, have remarkably converged, just as it was predicted by Eörsi's "veiled convergence" theory. ${ }^{45}$ Contrary to common law, civil law legal systems are based upon the principle of performance in kind, thus, promise appears to be enforceable, performable. "The principle of pacta sunt servanda, as has already been pointed out, was not merely a tenet enforced by the State but was on a highly respected place in the moral value scale. (...) The pacta sunt servanda principle was based on the 'sanctity' of private ownership and the

${ }^{44}$ Cicero: On Duties (De Officiis). In: Cicero, M. T.: Brutus, On the Nature of the Gods, On Divination, On Duties. Chicago, 1950, 473-474. Of course, Cicero is not duty-absolutist. "But occasions often arise, when those duties which seem most becoming to the just man... undergo a change... It may, for example, not be a duty to restore a trust or to fulfil a promise, and it may become right and proper sometimes to evade and not to observe what truth and honour would usually demand." See ibid. 475 . 216.

${ }^{45}$ See Eörsi: Összehasonlító polgári jog and Comparative Civil (Private) Law. op. cit. 
will of the private owner: it protected private ownership by attaching to the freedom of will the acceptance of responsibility for freely resolved acts."

In practice, however, legal systems that insist upon pacta sunt servanda offer a choice to the adversely affected party between performance in kind and damages. Despite the culture of will, promise is a ticket to a game where one either performs or pays according to the intent of the other party. Why would one insist on performance in kind by a party who already caused much trouble, when the problem can be easily settled through the market? The market of modern economy offers innumerably more options of covering purchase than closed society that was familiar to the Pandectists. The binding force of promise is weakened further in the light of the object of compensation, i.e. what damages are meant to cover, what state should the promisee be put via compensation. Does compensation really put a promisee in a state which he would have been, had the promise been kept? The answer goes in the negative in the legal systems of virtually modern market economies. The state of affairs as promised is rarely ever the sole controlling factor. Typically, courts take into consideration the actual (or reasonably expectable) conduct of the acceptor. In this respect, the reliance theory of common law provides the most straightforward example, allowing compensation only for damages occurring in relation to conduct in reliance of the promise. Thus, compensation is based not on promise, but on the trust of the other party. In cases where only actual damages are covered the concept of restitution delivers a similar outcome in continental legal systems. In addition, Hungarian law imposes an active duty on the promisee to mitigate damages. The notion of damages does not cover the collapse of the promisee's personal expectations. Law is indifferent to mental frustration. De minimis non curat. Humiliation and unremedied resentment, even if cause by public authorities, belong to human condition. The other is not hell, but the business partner is at least purgatory.

Consequently, while modern contract law, and especially continental contract law, preserves some components that refer to an obligation stemming from promise, the predicting force of a heteronymous concept of obligation is still greater. Nonetheless, even the latter is not asserted in a consistent manner, partly because of legal policy considerations (i.e. the

\footnotetext{
${ }^{46}$ Eörsi: Összehasonlító polgári jog. op. cit. 247. and Eörsi: Comparative Civil (Private) Law. op. cit. 265. Eörsi, at this stage of the discussion, points to the impact on others (contractual partners and third parties) as the basis for the social bindingness of the contractual obligation (for "bearing liability").
} 
judiciary's convenience), and partly on the basis of references to material justice.

When contract is cleaned from the ornaments of the phraseology of legal ideology, the difference between promise based on individual autonomy and facts constituting contracts is striking. From the perspective of moral of autonomy, contract, and even law as such, is amoral, or more precisely, immoral. Considerations relevant for concluding contracts can not contribute to the respect for promises, to reinforcing the moral order of freely assumed duties. Contract law turns its back on autonomy. In Germany, perhaps because it was impossible to live with the burdens imposed by omitting to repair the flaws of the BGB, courts reformulated contract law in the name of the principle of Treu and Glauben-and not only in cases where the parties were silent. Working against allegedly insensitive and selfish private autonomy, reformulation took place in the name of ad hoc social justice.

In the history of contract law there were several attempts to link contracts with moral concepts other than the one based on promise. While such attempts may comply with the political agenda of the day, due to their judicial arbitrariness and desultoriness, they can not serve predictability. In order to define ethical standards, they refer to vague ideas of justice expressed in legal norms; such ethical standards are meant to determine which elements of a promise should be kept. ${ }^{47}$ According to this approach, justice dictates that a promise may establish a contractual obligation only by way of acceptance. The disciples of Pythagoras taught that justice lied in reciprocity. "Therefore the just is intermediate between a sort of gain and a sort of loss, viz. those which are involuntary; it consists in having an equal amount before and after the transaction." 48 It would be unjust in respect to commutative justice if one party failed to react in exchange for the actions of the other party. Promise becomes binding by way of acceptance and performance: as a gesture of avoiding injustice. Only such promises are binding that serve a just purpose, leading to the requirement equivalence of values exchanged.

Still, there are logical difficulties concerning the assertion of just promises. The requirement of commutative justice will not resolve the problem arising

\footnotetext{
${ }^{47}$ As an advocate of this standpoint, see Kronman, A.: Contract Law and Distributive Justice, Yale Law Journal, 1980. 472.

${ }^{48}$ Aristotle: Nicomachean Ethics. In: The Complete Works of Aristotle. The Revised Oxford Translation (ed.: Jonathan Barnes). vol. 2.; Princeton, 1995, 1787 [1132b].
} 
from situations where both parties had made their promises but neither has performed yet. This problem is typical in consensual theories. When neither promise is enforced, commutative justice is not violated. Benevolent donations may cause further problems. Following Aristotle, Thomas of Aquinas proclaimed that, in respect to promises and gifts there is no reciprocity, while there clearly is a duty. Law must enforce promises serving virtue and justice. This ethical approach is reinforced by claims concerning material justice and by the entire social conception of law.

Suppression of the moral of promise in contract law is more than a simple change in ideology. Reference to morality affects obedience to law. It does matter whether the glaze is made of paper or burned sugar. Crème brulee is all about the glaze-try to replace it with cardboard. In the context of contracts, governmental coercion to enforce contracts or damages is accepted, and-even more-expected, because in doing so government acts in accordance with the requirements of good morals. It takes a closer analysis to show that moral expectations are irrelevant for the state, and that the state considers not the position of the one who is acting, but the position of the one who is expecting. Moreover, law determines when and to what extent a promise is worthy of enforcement without being consistent about moral standards. It is certain that law tends to promote the cause of the victims quiet inconsistently, at least as a pro forma gesture of self-justification. This still seems to be sufficient to preserve the façade of law's "morality". This is all what is left from the concept of "law's ethical minimum". It is still another issue, whether society is willing to acknowledge legal norms and their enforcers as effective safeguards of moral order on the basis of actual legal norms and their enforcement.

\section{What is Contract Law For, or, To What Extent is It Possible to Divert Legal Conventions Towards an Individual Moral Course?}

Gyula Eörsi would be right in finding the lament on the decline of the morals of promise outdated. ${ }^{49}$ After all, the mobilising slogans of contemporary law are stabilisation of monopoly capitalist economy, socialwelfare issues, the "protection of the weak", economic and legal efficiency. However, there is no lamentation here, since as Vilmos Peschka rightly observed, subjective morality in itself can not determine the ethical. ${ }^{50}$ It is still considerable whether autonomy may influence law at all via ethics, this

${ }^{49}$ Eörsi: Comparative Civil (Private) Law. op. cit. See his discussion of Riperts ideas.

${ }^{50}$ See Peschka, V.: Az etika vonzásában (Attracted by Ethics). Budapest, 1980, 128. 
distillation of momentary truths. Keeping in mind the characteristics of law, a consistently promise-based law might not even be necessary. It is still noteworthy, though, that moral as reflected in socially filtered ethics determining law appears as distant memories of a teenage love affair.

Even Kant did not hold that morals may determine law, or may determine actions against the law. He regarded legal obligations as autonomous. Nonetheless, it is worth reconsidering the critical and assertive role moral premises may have vis-à-vis law. The mirror held by the morals of autonomy in front of the contracting party and contract law reflects a rather unattractive image. Codification attempts in the 19th century aimed to save the world from jurisprudence and unjust customs. ${ }^{51}$ Legislation could not find a better task ever since. What is the task of contract law, that is, of legal rules applicable to contracts? Can it promote the autonomy of the parties, if that holds one of the parties captive? What kind of justice can it impose upon the parties, and to what extent? By what dictates of reason does it remedy the weak predictive capacities of contracting parties and their treatment of unforeseeable events?

Upon the morals of promise it was (and still is) possible to draft such laws for contracts, which would be more consistent about justice than the kind of material justice that invades contracts jurisprudence and suppresses autonomy. Promise-autonomy could become a basis for more stringent legal rules, which are not based on reliance. Such rules are not necessarily less effective than contemporary solutions. One-sided mightiness may well be reduced on Kantian premises, keeping in mind that one's freedom does not go beyond the boundaries of the freedom of other's. Within such a concept, abuse of power may result in invalidity without having to give way to convoluted attempts of judicial paternalism in the name of material justice. As Lajos Vékás observed "social requirements concerning social justice proved stronger than any ideal and classical principle ... [I]n industrialised societies assuring the common good to the greatest possible extent is possible by way of a democratic form of government". ${ }^{52}$ It does not follow, however, that this would require a kind of openness that renders possible nothing but judicially assisted business pragmatism and statutory intervention that satisfies the needs of political populism without consistent governmental enforcement measures.

${ }^{51}$ See Wieacker, F.: A History of Private Law in Europe. Oxford, 1995, 258.

${ }^{52}$ Vékás, L.: Gondolatok az új polgári törvénykönyv elé (Preliminary Thoughts to the New Civil Code). In: Van és legyen a jogban: Tanulmányok Peschka Vilmos 70. születésnapjára (Is and Ought in Law: Essays for the 70th Birthday of Vilmos Peschka). Budapest, 1999, 358. 
It is not at all peculiar for dispositive (and, incidentally, cogent) statutory provisions to remedy gaps opened by carelessness or lack of time. The question rather is when comes the time for legal intervention to fill those gaps. According to Oliver Wendell Holmes, the point of departure for law is the "bad man". This is a reasonable and justified assumption, especially if one expects law to protect society from "bad men", including those cheating and lying when entering into contracts. But legal regulation based on a pragmatic conception may collide with a legal order based on autonomous morality. The latter being a legal order envisioned by legislators who do not intend to protect the members of society, but rather, intend to create such circumstances within which a person is a human being of moral choice.

Promise may give rise to moral obligation if the promisor is rational, if he is able to render his actions universal (as demonstrated in the case of the promisor not willing to repay a loan). But this is regarded, even by Kant, not as an empirical but a normative condition: man has to be seen this way in order to be able to free him from his age of infancy one day. Knowledge, time, and information instrumental to reasonableness are limited. As an intellectual exercise, it is hard, costly, and-for the same reason-almost impossible to foresee the entire scope of an undertaking, to settle the risks in advance. Within certain limits, the legislator takes care of establishing a universal law, which contracting parties were not capable of, due to their intellectual or moral infancy, or hedonism. Legal provisions regulate some eventualities not foreseen by the promisor, in a manner as it is expectable from a reasonable man. (Then, the empirical legislator soon arrives at trade customs as depositories of universalizable maxims of action.) Most rules of contract law are dispositive, and that allows for deviations from this supposed reasonableness. In certain cases, the legislator's efforts to make universal moral law into law might also mean including Kantian requirements therein. The legislator, playing the role of the Kantian man in place of contracting parties, declares that contractual clauses that treat other people as mere instruments are contrary to good morals. While a theory of law might promote morals, when following such laws one's actions will be only legal, and not moral.

There is a further difficulty regarding intellectual capacities and characteristics of everyday knowledge, which shall be remedied by law. In the Kantian examples, the promisor's determination to perform is unlimited as much as his ability to perform is. The promisor did not only decide (and, thus, obliged) to pay 50 pounds, but he is able to do so. In reality, however, as promises are attempts to rule the future, even such a simple case is heavy with uncertainties that may disturb the fulfilment of a promise, or 
may require its ex post revision. What if the 50 pound note was stolen, before it could have been handed over? What if by the time performance is due, the promisor becomes impoverished and lives on begging? What if by the time of performance the 50 pound note is worth nothing? The promisor's consciousness can not encompass such cases-law has to make up for it. And, especially in the case of contracts with consideration, law can not let the promisor determine ex post about what he wanted in the first place. May one insist upon a principle or a narrative of promise, will, or declaration, one has to hold that in law promise continues its own legal existence. Autonomy turns into heteronomy. What remains of freedom is submitting to a game by-at least from one's perspective-arbitrary rules. To conclude, in contrast to the Kantian assumption, law attributes legal significance to a will which is not fully determined: in real life, economic and other relations are run upon indeterminate obligations and partial promises. There is room for conditional promises and options. There is engagement before marriage that has legal consequences in many legal systems. The factual is taken as an obligation, it is elevated to the status of promise.

Law can not handle promise as giving rise to moral obligation, for as in law and in everyday life - the preconditions of autonomous promises are lacking. Regulations substitute these deficiencies with other assumptions. The first unrealised assumption is that a promise is made by a reasonable man, who can universalise his actions and their consequences. For this reason, many legal prohibitions prohibit promises. For instance, a contract is against good morals if it binds one party, while the performance of the other party depends on the occurrence of some event depending exclusively on his own intentions. This rule, already incorporated in the law of the European Communities, intends to secure universalisable promises. ${ }^{53}$ (From the perspective of Aristotelian ethics, such a rule might constitute a violation of distributive justice. One does not have to go that far, since such rules may also be made to protect autonomy.)

If the binding force of promise is explained by submitting that in a promise the promisor recognizes himself as an intelligent and autonomous being (without which one can not expect to be recognised as such), why

\footnotetext{
${ }^{53}$ Directive 93/13/EEC of 5 April 1993 on unfair terms in consumer contracts. Annex 1). Cf. 10. § (3) of the German Allgemeine Geschäftsbedingungsgesetz: "(Rücktrittsvorbehalt) Klauselverbote mit Wertungsmöglichkeit, In Allgemeinen Geschäftsbedingungen ist insbesondere unwirksam die Vereinbarung eines Rechts des Verwenders, sich ohne sachlich gerechtfertigen und im Vertrag angegebenen Grund von seiner Leistunfgsplicht zu lösen; dies gilt nicht für Dauerschuldverhältnisse.”
} 
does this have such a minimal relevance in contract law? The answer lays in the amorality of the world, of human relations and of law. Or, to phrase it in an even sharper manner, in a contract one does not only make a promise about goods or services: when concluding a contract, one also enters into an agreement about his trustworthiness (fidelity) and establishes a standard of expectations concerning the other party. This is demonstrated in contractual default penalties and liquidated damages, although indemnification, unilateral termination, and exemption from performance (even if they typically concern external circumstances) may also be mentioned here. Liquidated damages are far the best example: in case of breach of contract by the other party, in exchange for proper assignment, the obligee agrees to settle for part of the expected benefit. Thus, the obligee gives up part of the initially expected performance in exchange for a secondary, more secure performance. ${ }^{54}$ Promise is transformed in the contract. It is not promise that matters but the extent to which the acceptor takes it seriously: the more seriously he takes it on the level of facticity (see reliance), the stronger the binding force of promise will be-although it is all a matter of agreement. Damages are not adjusted to reliance generated by the promise, but to the extent to which it was possible to rely on the promise on the basis of the agreement, or to the extent the obligee did actually rely on the promise. But even this brings by a practical legal twist: acceptance does not justify the obligee's unconditional confidence; it justifies what the court regards as acceptable according to trade considerations. At best, the standard is efficiency and de facto custom.

\section{Conclusions}

The relationship between promise as a moral category and facts treated as promise in law is almost accidental. If, at the outset, there was some ground to believe that law, and contract, should correspond with moral requirements of promise on an elementary level, now it seems that law is at least indifferent to factors that give rise to moral obligation based upon a promise. Perhaps it is beneficial that law was liberated from the tutelage of morals, as this way law was made more efficient. Nonetheless, law has become morally empty. Even public law references to autonomy serve the limitation of freedom.

\footnotetext{
${ }^{54}$ See Craswell, R.: Against Fuller and Perdue. The University of Chicago Law Review, 2000. 114.
} 
Law uses terms that refer to morals and legislation-at least for public purposes-has insisted for a long time (and perhaps even today) that it asserts at least a moral minimum. In fact, however, for internal use, law is proud that its ethically tainted terms gained predictable doctrinal content as seen in the case of good faith or intent. That pride is truly justified for arbitrariness begins with the application of dogmatically undigested terms, where cases are decided with reference to brute public interest. Those cases follow the bare logic of power, the dictates of private interests. The separation of law and morals was widely celebrated-and there was something emancipating in it, paradoxically in the same sense as morals were sought in the present analysis. When emancipated from the dictates of morals, law served freedom better than legal norms formulated in morally coloured legal systems until the 19th century.

Other moral critics hold law responsible for the loss of freedom, presupposing that, following bourgeois revolutions, freedom was to be served by law. Indeed, even if law was a means of social liberation, it is to be received with reservations. Bourgeois revolutions-taking the French Declaration of 1789 seriously_promised freedom only within the framework of statutes: the private law of the Code Civil was freedom-loving only in its rhetoric. The record of classical private law in guaranteeing freedom is certainly remarkable, since it made possible all sorts of transactions among a growing number of people and even enforced these under certain conditions. However, freedom was of secondary importance for law, although, in respect to freedom (as can be experienced once again today), it is pleasing when public administration is bound by law. As far as private law, and contract law, is concerned, beyond rhetoric, it did not centre around freedom and autonomy. It strived for a kind of institutional or economic efficiency. Ethical or moral rhetoric has survived at least in part, but gradually it is losing its significance. According to Eörsi's summary-that does not sound melancholic or resigned at all-modern law is centred around problems that can not be solved by axiomatic methods as society is too complicated for their application. "Legal system as a coherent conceptual system has failed, and its constituents are now independently used for part-purposes which are often mutually contradictory."

\footnotetext{
${ }^{55}$ Eörsi: Comparative Civil (Private) Law. op. cit., 167.
} 